\title{
Evaluation of Resin Explosion Effect on Facility Worker in HB-Line Phase II
}

by

D. F. Hailman

Westinghouse Savannah River Company

Savannah River Site

Aiken, South Carolina 29808

This paper was prepared in connection with work done under the above contract number with the U. S. Department of Energy. By acceptance of this paper, the publisher and/or recipient acknowledges the U. S. Government's right to retain a nonexclusive, royalty-free license in and to any copyright covering this paper, along with the right to reproduce and to authorize others to reproduce all or part of the copyrighted paper. 


\section{DISCLAIMER}

This report was prepared as an account of work sponsored by an agency of the United States Government. Neither the United States Government nor any agency thereof, nor any of their employees, makes any warranty, express or implied, or assumes any legal liability or responsibility for the accuracy, completeness, or usefulness of any information, apparatus, product or process disclosed, or represents that its use would not infringe privately owned rights. Reference herein to any specific commercial product, process or service by trade name, trademark, manufacturer, or otherwise does not necessarily constitute or imply its endorsement, recommendation, or favoring by the United States Government or any agency thereof. The views and opinions of authors expressed herein do not necessarily state or reflect those of the United States Government or any agency thereof.

This report has been reproduced directly from the best available copy.

Available for sale to the public, in paper, from: U.S. Department of Commerce, National Technical Information Service, 5285 Port Royal Road, Springfield, VA 22161

phone: (800) 553-6847

fax: (703) 605-6900

email: orders@ntis.fedworld.gov

online ordering: http://www.ntis.gov/ordering.htm

Available electronically at http://www.doe.gov/bridge

Available for a processing fee to U.S. Department of Energy and its contractors, in paper, from: U.S. Department of Energy, Office of Scientific and Technical Information, P.O. Box 62, Oak Ridge, TN 37831-0062

phone: (865)576-8401

fax: (865)576-5728

email: reports@adonis.osti.gov 
NMS\&S ENGINEERING

TECHNICAL SUPPORT

WSRC-TR-2001-00050

REVISION: 0

KEYWORDS:

Explosion

Resin

Worker Protection

\section{EVALUATION OF RESIN EXPLOSION EFFECT
HB-LINE PHASE II}

Retention:

February 6, 2001

10. Years 


\section{Revision History}

Rev. 0, 2/6/2001

Initial Issue 
TABLE OF CONTENTS

\begin{tabular}{|l|l|l|}
\hline & \multicolumn{1}{|c|}{ Section } & Page \\
\hline & Revision History & 2 \\
\hline & Table of Contents & 3 \\
\hline 1 & Summary & \\
\hline 2 & Introduction & 4 \\
\hline 3 & Methods of Analysis & 4 \\
\hline 4 & Results & 4 \\
\hline 4.1 & Non-Radiological Consequences & 5 \\
\hline 4.2 & Radiological Consequences & 5 \\
\hline 5 & Assumptions & 5 \\
\hline 6 & Recommendations & 7 \\
\hline 7 & References & 7 \\
\hline & & 8 \\
\hline & & \\
\hline & & \\
\hline
\end{tabular}




\section{Summary}

Page 4 of 8

The consequences of a Phase II resin-nitric acid autocatalytic reaction have been evaluated for the public and the onsite worker elsewhere. This Technical Report documents the effects of a resin-nitric acid autocatalytic reaction on the facility worker, conservatively assumed to be in the operating area for the resin columns. If specified relief devices are installed on the eight-inch resin columns, the non-radiological consequences to the facility worker are low. If neither the glovebox exhaust system nor respiratory protection is credited, the radiological consequences to the facility worker are moderate for a resin column autocatalytic reaction, and low for an autocatalytic reaction

$=$ in the Nuclear Resin Catch Tank (NRC tank). If either the glovebox exhaust system or

- respiratory protection is credited, the radiological consequences to the facility worker are low for either event.

\section{Introduction}

HB-Line Phase II uses plutonium solutions as feed and converts plutonium in these solutions to solid plutonium oxide for either storage or further processing. Plutonium is purified and concentrated using anion exchange columns. There have been instances of autocatalytic reactions within the DOE complex and elsewhere when using nitric acid solutions for processing material in anion exchange columns (Reference 1). Some of these events have ruptured glass and metal columns containing anion resin. HB-Line is implementing controls to prevent this event and to mitigate the results of the event to the public, onsite worker, and facility worker (Reference 2). These controls include a design change to add a rupture disk to the eight-inch columns that will be used for plutonium solution processing. This rupture disk will maintain the column pressure at or below 60 psig if an autocatalytic reaction occurs between the nitrate-form resin and nitric acid, (Reference 3).

An autocatalytic reaction, if not interrupted, can result in an explosion. By adding a rupture disk to the eight-inch resin columns, the reaction is vented before it progresses to an explosion. The rupture disk prevents a resin column explosion. Similarly, rupture of the sight glass in the NRC tank vents this reaction before an explosion occurs.

This Technical Report evaluates the consequences to the facility worker if an autocatalytic reaction of nitric acid and anion resin occurs, either in an eight-inch resin column or in the NRC tank.

\section{Methods of Analysis}

The potential for generating energetic fragments that could impact facility workers is considered, and a control to prevent this occurrence is assumed. The capability of the gloveboxes to contain radioactive material ejected from the eight-inch anion columns and the NRC tank, if an autocatalytic reaction occurs, is evaluated. The impact of "rclief" devices on the gloveboxes that prevent filling the ion exchange cabinets with water on 
potential radioactive material releases from the gloveboxes is evaluated. The effects of the glovebox exhaust system, and respiratory protection for the workers, are considered.

\subsection{Results}

\subsection{Non-radiological Consequences}

Since the resin column pressure excursion will be limited to 60 psig by a rupture disk (Reference 3 ) and the resin column is designed to withstand $60 \mathrm{psig}$ internal pressure $\exists$ under normal conditions, no energetic fragments will be generated. The NRC tank has a Z. $\quad$ sight glass incorporated into its design (Reference 4). This sight glass will rupture at between 190 and 320 psig (Reference 5), and this limits the pressure the tank will experience. The glovebox will contain sight glass fragments and no energetic metal fragments will be formed before the sight glass yields.

An autocatalytic reaction between nitrate-form anion resin (in either the eight-inch columns containing a rupture disk or the NRC tank) and nitric acid does not result in fragments with enough energy to escape the glovebox. An autocatalytic reaction in the NRC tank is expected to fracture the sight glass incorporated into one side of this slab tank, but the glass fragments will not have enough energy to penetrate the glovebox. Therefore, the non-radiological consequences to the facility worker are low.

\subsection{Radiological Consequences}

Autocatalytic reactions develop when the reaction rate increases as the temperature of the reaction increases ("Arrhenius-type" reactions) and the heat of the reaction is sufficient to increase the temperature of the reactants without further heat being added from outside sources. Nitrate-form anion resin and nitric acid can undergo an autocatalytic reaction without proper controls. HB-Line implements controls to prevent this reaction. One of the controls implemented is an "ever-open" vent line from the resin column connected to the HB-Line vessel vent system. The NRC tank contains resin infrequently, but it also has a vent line connected to the vessel vent system. These lines are not adequate to vent the reaction products after the reaction rate increases significantly.

As discussed above, the vessels that may contain nitrate-form anion resin are vented by pressure-relief devices or inherent design characteristics so high pressures do not develop in these vessels if an autocatalytic reaction occurs.

One of the keys to preventing a resin-nitric acid explosion is to interrupt the reaction by venting reaction products and heat before the reaction rate increases significantly. The pressure increase in the vessels is faster, and the vessels relieve earlier to control the reaction, if reaction products cannot escape when the reaction is initiated. It is conservative to assume the vessels are vented to the vessel vent system through small (1/2-inch tubing) when evaluating radiological consequences to the facility worker. 
When the reaction products from the autocatalytic reaction can no longer be transported from the vessels by the small vent line, pressure builds until the vessels are vented through the rupture disk (eight-inch column) or the sight glass (NRC tank). Reaction products, heat, and a portion of the reactants are then vented from the vessels, controlling the reaction rate.

A 1.7-inch rupture disk is sufficient to vent the eight-inch columns containing 13,000 grams of resin (Reference 3). The NRC tank may contain twice this resin, from two charges of "spent" resin. The normal exhaust from the gloveboxes containing these vessels is greater than 300 CFM (Reference 6). The source of air to the gloveboxes is $=\quad$ entrance through HEPA filters and other inleakage; no air is supplied to the gloveboxes.

- Considering the relatively small size of the relief device that prevents the resin column

- from overpressurizing, no radioactive material will escape the gloveboxes if the glovebox exhaust system is credited as a mitigator.

Only a small fraction of the radioactive material that is on resin undergoing an autocatalytic reaction will become airbome. "Spent" resin in the NRC tank will not contain much radioactive material; the radioactive material will be eluted from the resin prior to transfer.

A glovebox drain may be installed in the gloveboxes, to prevent inadvertent buildup of water in the gloveboxes during firefighting activities. This drain may be a section of plastic tubing, open at both ends. One end would be attached to a gloveport from which the glove had been removed, and the remainder of the tubing would be maintained in a roll to minimize normal inleakage through this device. If the glovebox reaches a positive pressure, this drain would unroll and vent the positive pressure in the gloveboxes.

If the glovebox exhaust system were not operating, pressure generated within the glovebox would exit the glovebox through the entry HEPA filters, the relief device, or bagout ports. If the relief devices were installed, the pressure drop through the entry HEPA filters likely would be sufficient to cause the drains to open.

If the only openings in the gloveboxes are the drains or ruptured bagout sleeves, most of the radioactive material ejected into the glovebox will still be contained in the glovebox. Discharge will lower the pressure in the glovebox and, once the glovebox pressure equals the pressure outside the glovebox, discharge of radioactive material ceases. All air in the glovebox will not mix with room air.

The maximum radiological consequences to the facility worker would be relief of excess glovebox pressure into an operating area containing workers. The volume of the operating area is significantly less than of the maintenance area and would provide less dilution volume. The radiological consequences to a facility worker in operational areas with a glovebox drain bounds the consequences in other areas or configurations. 
If a glovebox pressurizes, workers would be aware of the event by sight and sound.

Workers would promptly evacuate the area. Airlocks are located at both ends of the operating and maintenance areas, so evacuation can occur promptly.

Workers in an operating area containing glovebox drains could have moderate radiological consequences. The consequences to workers in a maintenance area containing glovebox drains, or with bagout ports only, would be low because of the larger dilution factor afforded by the room volume.

If either the glovebox exhaust system or a requirement to wear respiratory protection - when in the operating or maintenance area are credited, the consequences to the facility - worker are low.

\subsection{Assumptions}

The key assumptions used in this report to derive the consequences to the facility worker are as follows.

1. A rupture disk, nominally two inches in diameter, will be installed on each operating eight-inch anion exchange column. The relief pressure for the rupture disk will be nominally 60 psig. Since the minimum rupture disk diameter required is 1.7 inches in diameter, it is not required to have disks with a rupture rating less than 60 psig to ensure 60 psig is not exceeded.

2. The gloveboxes will partially confine radioactivity vented from the eight-inch resin column or the NRC tank if an autocatalytic reaction occurs. This assumption is satisfied if the glovebox integrity is maintained in its normal configuration.

Compensatory measures are instituted during maintenance activities, such as panel removal, to protect workers during transient openings used during maintenance.

3. There are drains (plastic tubing) installed on two gloveports opening to Room 533. These will relieve overpressure in the gloveboxes caused by resin column/tank venting, if the glovebox exhaust fans are not operating. This assumption bounds the consequences to the facility worker. If the drains are located in the maintenance area or are not present, consequences to the facility worker would be low.

If either the glovebox exhaust system or a requirement to wear respiratory protection when in the operating or maintenance area are credited, the consequences to the facility worker are low.

\subsection{Recommendations}

Controls should be instituted to ensure conditions listed in the key assumptions are valid during ion exchange column operation. 


\subsection{References}

1. Miles, F. W., Ion-Exchange-Resin System Failures in Processing Actinides, Nuclear Safety, Vol. 9, No. 5, Sept-Oct 1968

2. NMS-ETS-2000-00137, Phase II Resin Controls to be Credited in AB Space, $8 / 4 / 2000$

3. WSRC-TR-2001-00064TL, Transmittal Letter for Fauske Report on Relief

- $\quad$ Sizing for HB-Line Resin Column, Blancett to Mobley, February 2, 2001

-. 4. D181360, Rev. 2, Calch Tank Details, 150 liter

5. T-CLC-H-00523, Pressure Evaluation of NRC Tank, January 25, 2001

6. W719760, Rev. 6, $5^{\text {th }}$ Floor Air Flow Diagram. Heating and Ventilation 